\title{
Khasiat dan Profil Kromatogram Fraksi Aktif dari Ekstrak Kulit Buah Manggis (Garcinia mangostana L.) yang Diiradiasi
}

\section{(Efficacy and Chromatrogram Profile of Active Fraction from Mangosteen Fruit Peel (Garcinia mangostana L.) Irradiation)}

\author{
ERMIN KATRIN ${ }^{1 *}$, SETIANANDA JACOBS ${ }^{2}$, HENDIG WINARNO ${ }^{1}$ \\ ${ }^{1}$ PAIR - BATAN, JI. Raya Lebak Bulus No. 49 Pasar Jumat, Jaksel 12440 \\ ${ }^{2}$ Fakultas Farmasi , Universitas Pancasila, Jl. Jagakarsa, Srengseng Sawah, Jaksel 12640
}

Diterima 18 Mei 2017, Disetujui 17 Juli 2017

\begin{abstract}
Abstrak: Kulit buah manggis (Garcinia mangostana L.) selain sebagai antiinflamasi, antihistamin, pengobatan penyakit jantung, antibakteri, antijamur, juga digunakan untuk pengobatan atau terapi kanker karena memiliki aktivitas sitotoksik pada sel kanker. Sebagian masyarakat Indonesia telah menggunakan kulit buah manggis dan membuat bubuk kulit manggis atau industri obat herbal telah memproduksinya sebagai ekstrak dalam kapsul. Usaha untuk mengawetkan kulit buah manggis kering dilakukan dengan pemanasan maupun dengan teknik iradiasi gamma. Penelitian ini bertujuan untuk mempelajari pengaruh iradiasi gamma pada aktivitas sitotoksisitas ekstrak dan fraksi aktif kulit buah manggis terhadap sel leukemia L1210 dan profil kromatogram ekstrak dan fraksi aktif dari kulit buah manggis. Serbuk kering kulit buah manggis diiradiasi gamma dengan dosis iradiasi 5; 7,5; 10; dan 15 kGy. Kemudian masing-masing sampel dimaserasi secara bertingkat dengan n-heksan, etil asetat, dan etanol. Setiap ekstrak diuji sitotoksisitasnya terhadap sel leukemia L1210. Ekstrak etil asetat meruupakan ekstrak paling aktif $\left(\mathrm{IC}_{50}=4,17 \mu \mathrm{g} / \mathrm{mL}\right)$ dibandingkan dengan ekstrak n-heksan $\left(\mathrm{IC}_{50}=8,29 \mu \mathrm{g} / \mathrm{mL}\right)$ dan ekstrak etanol $\left(\mathrm{IC}_{50}=7,52 \mu \mathrm{g} / \mathrm{mL}\right)$. Fraksinasi ekstrak etil asetat melalui kromatografi kolom diperoleh 6 fraksi. Hasil uji sitotoksisitas ke-6 fraksi tersebut menunjukkan bahwa fraksi 1 paling aktif $\left(\mathrm{IC}_{50}=\right.$ $3,66 \mu \mathrm{g} / \mathrm{mL})$, masih dalam batas aktif berpotensi antikanker $\left(\mathrm{IC}_{50} \leq 20 \mu \mathrm{g} / \mathrm{mL}\right)$. Profil kromatogram fraksi 1 dengan KLT-densitometri menunjukkan pemudaran bercak pada dosis iradiasi 10 dan $15 \mathrm{kGy}$. Hasil analisis fraksi 1 dengan KCKT menunjukkan penurunan luar area puncak pada dosis $10 \mathrm{kGy}$ yang berbeda nyata dengan kontrol. Berdasarkan profil kromatogram dan hasil pengujian sitotoksisitas terhadap sel leukemia L1210, maka dosis maksimum iradiasi gamma 7,5 kGy dapat diterapkan pada iradiasi kulit buah manggis tanpa mengubah khasiatnya.
\end{abstract}

Kata kunci: profil kromatogram, kulit buah manggis, iradiasi gamma, Garcinia mangostana, L., sitotoksisitas.

\begin{abstract}
The mangosteen fruit peel (Garcinia mangostana L.) are used as anti-inflammatory, antihistamine, treatment of heart disease, antibacterial, antifungal, it is also used for the treatment or therapy of cancer, because it has a cytotoxic activity against cancer cells. Most of Indonesian people have used the mangosteen fruit peel and they produce mangosteen peel into powder or herbal medicine industry has produced its extract in capsules. Efforts to preserve dried mangosteen rind has done by heating process or by gamma irradiation technique. This study aimed to study the effect of gamma irradiation on cytotoxicity activity of extracts and active fractions mangosteen fruit peel against L1210 leukemia cells and chromatogram profile of extracts and active fractions of the mangosteen fruit peel. Dry powder mangosteen rind irradiated using gamma irradiation dose of 5; 7.5; 10; and $15 \mathrm{kGy}$. Then each sample was successive macerated in n-hexane, ethyl acetate, and ethanol. Each extract was tested cytotoxicity against L1210 leukemia cells. The ethyl acetate extract was most active extract $\left(\mathrm{IC}_{50}=4.17\right.$ $\mathrm{mg} / \mathrm{mL})$ compared with n-hexane extract $\left(\mathrm{IC}_{50}=8.29 \mathrm{mg} / \mathrm{mL}\right)$ and ethanol extract $\left(\mathrm{IC}_{50}=7.52 \mathrm{mg} / \mathrm{mL}\right)$. Fractionation of ethyl acetate extract by column chromatography were obtained 6 fractions.
\end{abstract}

*Penulis korespondensi: Hp : 021-7690709 ext 179

Email: erminkk@batan.go.id 
The result of cytotoxicity test showed that fraction 1 was the most active fraction $\left(\mathrm{IC}_{50}=3.97 \mathrm{mg} /\right.$ $\mathrm{mL}$ ), it was it was still categorized as potential anticancer $\left(\mathrm{IC}_{50} \leq 20 \mathrm{mg} / \mathrm{mL}\right)$. Profile chromatogram of fraction 1 with TLC-densitometry showed patches of discoloration on irradiation dose of 10 and 15 kGy. The results of analysis by HPLC fraction 1 showed a decrease of peak area at a dose of $10 \mathrm{kGy}$ was significantly different from the control. Based on the chromatogram profile of fraction 1 and its cytotoxicity against L1210 leukemia cells, so the maximum dose of $7.5 \mathrm{kGy}$ gamma irradiation can be applied on irradiation of mangosteen fruit peel without changing its efficacy as anti-cancer agent.

Keywords: chromatogram profile, mangosteen fruit peel, gamma irradiation, Garcinia mangostana L., cytotoxicity.

\section{PENDAHULUAN}

TANAMAN obat tradisional telah banyak dimanfaatkan oleh masyarakat Indonesia untuk mengobati berbagai macam penyakit. Hal ini terbukti dengan semakin meningkatnya penggunaan obat tradisional dan meningkatnya produksi obat dari industri-industri obat tradisional. Upaya pembuktian khasiat tanaman sebagai sumber suatu obat menjadi pilihan utama saat ini bagi para peneliti obat di Indonesia.

Proses penemuan suatu obat dari suatu tanaman merupakan sesuatu yang tidak mudah dan membutuhkan waktu yang lama. Salah satu yang telah dimanfaatkan untuk tujuan tersebut adalah buah manggis (Garcinia mangostana L.), terutama pemanfaatan kulit buah manggis. Minat dan konsumsi masyarakat akan buah ini sangat tinggi, oleh karena itu kulit buah manggis memiliki potensi yang sangat besar untuk dikembangkan sebagai bahan obat.

Statistik (BPS), Indonesia pada tahun 2009 mengeksport sebanyak 8125 ton buah manggis dan pada tahun 2010 mengekspor sebanyak 9856 ton buah manggis ${ }^{(1)}$. Kulit buah manggis menunjukkan bahwa buah manggis mengandung beberapa senyawa dengan aktivitas farmakologi misalnya sebagai antiinflamasi, antihistamin, pengobatan penyakit jantung, antibakteri, antijamur, dan untuk pengobatan atau terapi $\operatorname{kanker}^{(2)}$.

Kulit buah manggis mengandung metabolit xanthone, 2 senyawa xanthone yang terbanyak adalah $\alpha$-mangostin dan $\gamma$-mangostin yang mempunyai bioaktivitas sebagai anti kanker kolon ${ }^{(3)}$. Warna ekstrak kulit buah manggis menunjukkan aktivitas anti oksidannya dari senyawa flavonoid dan senyawa fenolat yang dikandungnya ${ }^{(4)}$.

Bahan obat herbal harus tetap terjaga kualitas dan kebersihannya sampai pada konsumen. Proses yang perlu diperhatikan adalah sejak penanganan pasca panen tanaman obat harus ditangani dengan baik, dari proses pengumpulan, penyimpanan, dan pengolahan bahan. Pada setiap proses kontaminasi mikroba dapat terjadi, oleh karena itu diperlukan suatu teknik pengawetan simplisia yang tepat guna. Pada umumnya, teknik pengawetan simplisia dilakukan dengan menggunakan pemanasan pada suhu tertentu, iradiasi sinar ultraviolet, dan infrared. Teknik iradiasi gamma (2,5 kGy - $10 \mathrm{kGy})$ ini telah banyak digunakan oleh industri obat herbal untuk memperpanjang masa simpan simplisia maupun kapsul obat herbal ${ }^{(5)}$. Efek radiasi gamma terhadap khasiatnya penting untuk dipelajari, agar obat herbal yang telah diiradiasi tetap terjamin bahwa khasiatnya tidak mengalami penurunan, khususnya iradiasi kulit buah manggis yang belum pernah dilakukan. Penelitian ini bertujuan untuk mempelajari pengaruh iradiasi gamma pada aktivitas sitotoksisitas ekstrak dan fraksi aktif kulit buah manggis terhadap sel leukemia L1210 dan profil kromatogram ekstrak dan fraksi aktif dari kulit buah manggis dan berapa dosis maksimumnya.

Pada penelitian ini dilakukan uji sitotoksisitas ekstrak kulit buah manggis yang berpotensi sebagai antikanker, melalui pengujian sitotoksisitas secara in vitro terhadap sel leukemia L1210, profil kromatogram dari kromatografi lapis tipis (KLT) dan kromatografi cair kinerja tinggi (KCKT). Sampel yang digunakan bubuk kasar kulit buah manggis yang tidak diiradiasi (0 kGy/kontrol) dan sampel yang diiradiasi gamma dengan variasi dosis $(5 ; 7,5 ; 10$; dan $15 \mathrm{kGy})$.

\section{BAHAN DAN METODE}

BAHAN. Bahan digunakan pada penelitian ini adalah kulit buah manggis (Garcinia mangostana L.) yang telah kering dan diperoleh dari kebun manggis di Bogor dan sel leukemia L1210 (diperoleh dari The Institute of Chemical Research Jepang ${ }^{(9)}$. Bahan kimia yang digunakan, yaitu n-heksan, etil asetat, etanol, silika gel 60 mesh (70-230), metanol, celite 545 , lempeng silika GF254, larutan penampak bercak serium sulfat $1 \%$ dalam $\mathrm{H} 2 \mathrm{SO} 410 \%$, kloroform, RPMI-Medium 1640 (Gibco), tryphan blue, calf bovine serum (Gibco), sel leukemia L1210, akuabides dan metanol HPLC.

Alat. Alat utama berupa iradiator karet alam (IRKA), HPLC (Shimadzu C-R4A), spektrofotometer 
UV-VIS (HP8453), densitometer (camag), neraca analitik, penguap putar vakum/rotavapor (EYELA dan BUCHI), oven, kolom kromatografi, chamber KLT, pemanas listrik (hot plate), lampu UV (254 $\mathrm{nm}$ ), desikator vacuum, Laminar air flow, inkubator $\mathrm{CO}_{2}$, haemocytometer Neubauer improved, pencuci ultrasonik, alat-alat gelas, multi well plate tissue's culture, sero cluster plate dan mikroskop (Nikon HFX-DX).

METODE. Determinasi Tanaman. Identifikasi kulit buah manggis dilakukan di Herbarium Bogoriense, Pusat Penelitian Biologi, Lembaga Ilmu Pengetahuan Indonesia (LIPI), Cibinong.

Persiapan Sampel dan Iradiasi dengan Sumber Gamma $60{ }^{\circ} \mathrm{C}$. Kulit buah manggis dicuci bersih, dipotong-potong kecil dan dikeringkan, yang sudah dikeringkan selanjutnya diserbukkan, dan ditimbang. Sebelum iradiasi gamma, serbuk kering kulit buah manggis ditetapkan lebih dahulu susut pengeringannya. Hal ini bertujuan untuk mengurangi jumlah air dalam sampel, jika kandungan air $\geq 10 \%$ maka dapat menyebabkan pertumbuhan mikroba kembali setelah proses iradiasi. Bubuk kasar kulit buah manggis ditimbang dan dibungkus rapat dengan plastik polietilen, sebanyak 10 bungkus dengan berat masing-masing 100 gram. Sampel diiradiasi dengan sumber gamma $60{ }^{\circ} \mathrm{C}$ pada dosis $5 ; 7,5 ; 10 ; 15 \mathrm{kGy}$, masing-masing dosis dilakukan 2 kali ulangan.

Pembuatan Ekstrak Secara Maserasi. Sampel seberat 100 gram kulit buah manggis baik yang kontrol maupun yang telah diiradiasi, masing-masing diekstraksi secara maserasi (dingin) sebanyak 4 kali. Pelarut pertama yang digunakan yaitu n-heksan, lalu etil asetat dan pelarut yang terakhir etanol. Filtrat n-heksan, etil asetat, dan etanol masing-masing dipekatkan dengan menggunakan rotavapor vacuum pada suhu lebih kurang $32^{\circ} \mathrm{C}$ hingga diperoleh ekstrak kental. Ekstrak kental tersebut kemudian di vakum sampai diperoleh bobot konstan.

Uji Aktivitas Sitotoksik Ekstrak terhadap Sel Leukemia L1210 ${ }^{(6)}$. Sampel ekstrak n-heksan, etil asetat, dan etanol dari sampel kulit buah manggis yang tidak diiradiasi (kontrol), masing-masing dibuat dengan variasi konsentrasi 5, 10, 20, 40, dan $80 \mu \mathrm{g} / \mathrm{mL}$ media RPMI-Medium 1640 yang telah mengandung suspensi sel leukemia L1210. Media ini dimasukkan ke dalam multi well plate tissue's culture sebanyak $990 \mu \mathrm{L}$ dalam setiap sumuran; metanol 10 $\mu \mathrm{L}$ kontrol digunakan sebagai kontrol pada pengujian sitotoksisitas terhadap sel leukemia L1210. Suspensi sel yang mengandung zat uji diinkubasi selama 48 jam pada $37{ }^{\circ} \mathrm{C}$ dalam inkubator $5 \% \mathrm{CO}_{2}$. Setelah 48 jam, jumlah sel dihitung dengan memipet $90 \mu \mathrm{L}$ suspensi dimasukkan ke dalam sero cluster plate $(96$ sumuran), ditambah $10 \mu$ larutan tryphan blue 1\% lalu dihomogenkan. Sel dihitung pada bilik hitung pada haemocytometer Neubauer improved. Setelah itu jumlah sel yang masih hidup dihitung di bawah mikroskop dan persentase penghambatan zat uji terhadap pertumbuhan sel leukemia L1210 dihitung.

Fraksinasi Ekstrak Paling Aktif dengan Kromatografi Kolom. Ekstrak paling aktif difraksinasi dengan kromatografi kolom menggunakan adsorben (fase diam) silika gel 60 (70-230 mesh). Pemisahan dilakukan dengan pengeluasi sistem gradien menggunakan eluen n-heksan-etil asetat $((10: 1),(5: 1),(3: 1),(1: 1))$, etil asetat, kloroformmetanol ((30:1), (15:1), (10:1), (5:1)), dan metanol. Volume masing-masing fraksi ditampung 150 $\mathrm{mL}$. Fraksi-fraksi yang diperoleh, masing-masing dikeringkan kemudian divakum hingga diperoleh bobot konstan.

Analisis Kromatografi Lapis Tipis (KLT). Fraksi-fraksi hasil fraksinasi kolom dari sampel kontrol selanjutnya dianalisis dengan KLT pada lempeng silika gel $\mathrm{GF}_{254}$ kemudian dieluasi dengan eluen yang sesuai. Setelah itu bercak diamati di bawah lampu UV $254 \mathrm{~nm}$ dan $366 \mathrm{~nm}$. Lempeng disemprot dengan pereaksi serium sulfat $1 \%$ dalam $10 \%$ asam sulfat lalu dipanaskan dengan pemanas listrik (hot plate) hingga terbentuk bercak tetap. Fraksi-fraksi dengan pola yang sama digabung sehingga dapat disederhanakan menjadi 7 fraksi. Analisis KLT juga dilakukan terhadap fraksi aktif dari masing-masing sampel yang diradiasi dan kontrol yang diperoleh dari hasil uji aktifitas sitotoksik terhadap sel leukemia L1210.

Uji Aktivitas Sitotoksik Fraksi Aktif dari Sampel yang Tidak Diiradiasi terhadap Sel Leukemia L1210. Pengujian aktivitas sitotoksik dilakukan pada fraksi-fraksi dari sampel kontrol yang dibuat dengan variasi konsentrasi 1, 2, 4, 8, dan 16 $\mu \mathrm{g} / \mathrm{mL}$. Penentuan aktivitas sitotoksik dilakukan sama seperti pengujian terhadap ekstrak. Fraksi paling aktif berpotensi antikanker dianalisis lebih lanjut untuk melihat profil kromatogramnya.

Analisis KLT - Densitometri dari Fraksi dan Ekstrak Paling Aktif. Fraksi 1 dan ekstrak etanol dengan dosis $0 ; 5 ; 7,5 ; 10 ; 15 \mathrm{kGy}$, masing-masing ditimbang dengan berat yang sama. Kemudian $40 \mu \mathrm{L}$ ditotolkan pada lempeng silika gel $\mathrm{GF}_{254}$ dan dieluasi dengan diklorometan:metanol (30:1) dan $\mathrm{CHCl}_{3}$ : metanol:air (6:4:1). Selanjutnya hasil eluasi dianalisis dengan densitometer pada panjang gelombang $210 \mathrm{~nm}$ dengan jarak rambat $10 \mathrm{~cm}$ untuk mengetahui luas bercak masing-masing kromatogram dari KLT fraksi 1 dan ekstrak etanol.

Analisis Kualitatif Fraksi Paling Aktif secara 
Spektrofotometri UV-Vis. Fraksi yang paling aktif dengan variasi dosis iradiasi dilarutkan dalam etil asetat hingga dapat diperoleh pembacaan serapan diantara $0,2-0,8$. Serapan fraksi aktif diukur dengan spektrofotometer UV-Vis pada panjang gelombang 200-800 nm untuk mencari panjang gelombang maksimum yang akan digunakan pada analisis fraksi aktif dengan metode KCKT. Serapan dari fraksi aktif dari sampel iradiasi akan dibandingkan dengan sampel kontrol untuk melihat apakah ada perubahan akibat iradiasi gamma.

Analisis Kromatografi Cair Kinerja Tinggi (KCKT). Pemeriksaan profil kromatogram dari fraksi paling aktif kulit buah manggis kontrol dan yang diiradiasi gamma dianalisis dengan kromatografi cair kinerja tinggi (KCKT). Sampel ditimbang dengan berat $20 \mathrm{mg} / \mathrm{mL}$ metanol. Larutan disaring menggunakan membran filter berukuran $0,45 \mu \mathrm{m}$ sebelum digunakan. Sebanyak $20 \mu \mathrm{L}$ larutan diinjeksikan ke KCKT dengan menggunakan campuran fase gerak metanol dan air dengan perbandingan (95:5). Sampel yang diinjeksikan sebanyak $20 \mu \mathrm{L}$ pada KCKT, kolom C-18 pada panjang gelombang $317 \mathrm{~nm}$ dan kecepatan alir $1 \mathrm{~mL} /$ menit.

\section{HASIL DAN PEMBAHASAN}

Hasil determinasi yang dilakukan di Herbarium Bogoriense, Bidang Botani Pusat Penelitian Biologi, LIPI Cibinong terhadap tanaman yang digunakan dalam penelitian menunjukkan bahwa tanaman tersebut adalah Garcinia mangostana L. Hasil penetapan susut pengeringan serbuk kering kulit buah manggis adalah 7,75\%, hal ini sesuai dengan persyaratan cara pembuatan simplisia, yaitu kurang dari 10\%. Hasil ekstraksi kulit buah manggis secara bertahap dengan pelarut n-heksan, etil asetat, dan

Tabel 1. Hasil ekstraksi ekstrak kulit buah manggis.

\begin{tabular}{|c|c|c|c|c|c|c|}
\hline \multirow[t]{2}{*}{ Ekstrak } & \multirow{2}{*}{$\begin{array}{l}\text { Dosis } \\
\text { Iradiasi } \\
(\mathrm{kGy})\end{array}$} & \multirow[t]{2}{*}{ Wama } & \multicolumn{2}{|c|}{ Bobot Ekstrak (g) } & \multirow[t]{2}{*}{ Rata -rata } & \multirow{2}{*}{$\begin{array}{c}\text { Rendemen } \\
(\%)\end{array}$} \\
\hline & & & Simplo & Duplo & & \\
\hline \multirow{5}{*}{ n-heksan } & 0 & Kuning & 1,0943 & 0,6372 & 0.8658 & 0,87 \\
\hline & 5 & Kuning & 0,8973 & 0,9186 & 0,908 & 0,91 \\
\hline & 7,5 & Kuning & 0,7915 & 0,7896 & 0,7906 & 0,79 \\
\hline & 10 & Kuning & 0,7216 & 0,7913 & 0,7565 & 0,76 \\
\hline & 15 & Kuning & 0,9386 & 0,8693 & 0,904 & 0,9 \\
\hline \multirow{5}{*}{ Etil asetat } & 0 & Coklat & 7,0022 & 7,1854 & 7,0938 & 7,09 \\
\hline & 5 & Coklat & 7,9121 & 7,5765 & 7,7443 & 7,74 \\
\hline & 7,5 & Coklat & 7,5896 & 7,3021 & 7,4459 & 7,45 \\
\hline & 10 & Cokllat & 7,0661 & 7,0598 & 7,063 & 7,06 \\
\hline & 15 & Coklat & 7,5861 & 7,5834 & 7,5848 & 7,58 \\
\hline \multirow{5}{*}{ Etanol } & 0 & Merah & 10,3456 & 10,7898 & 10,5677 & 10,57 \\
\hline & 5 & Merah & 10,0056 & 10,2534 & 10,1295 & 10,13 \\
\hline & 7,5 & Merah & 10,9631 & 10,5901 & 10,7766 & 10,78 \\
\hline & 10 & Merah & 10,259 & 10,9487 & 10,6039 & 10,6 \\
\hline & 15 & Merah & 10,0351 & 10,4809 & 10,258 & 10,26 \\
\hline
\end{tabular}

etanol ditunjukkan pada Tabel 1.

Hasil ekstraksi dari etanol memiliki rendemen perolehan hasil yang paling banyak, kemudian etil asetat dan n-heksan. Ekstrak n-heksan yang diperoleh berwarna kuning, ekstrak etil asetat berwarna coklat, dan ekstrak etanol berwarna merah kehitaman.

Masing-masing ekstrak dari sampel kontrol (0 kGy) dilakukan uji aktivitas sitotoksik terhadap sel leukemia L1210. Hasil uji aktivitas dapat dilihat pada Tabel 2, berdasarkan nilai $\mathrm{IC}_{50}$ ekstrak etil asetat merupakan ekstrak yang paling aktif berpotensi sebagai anti kanker dengan nilai $\mathrm{IC}_{50}=4,17 \mu \mathrm{g} / \mathrm{mL}$. Menurut Hostettmann K. bahwa ekstrak dikategorikan aktif berpotensi sebagai anti kanker bila nilai $\mathrm{IC}_{50}$ nya $<20 \mu \mathrm{g} / \mathrm{mL}^{(7)}$. Identifikasi kromatografi lapis tipis ekstrak etil asetat kulit buah manggis kontrol dan yang diiradiasi ditunjukkan pada Gambar 1. Pada masingmasing ekstrak terdapat 3 bercak berwarna kuning baik pada kontrol maupun sampel yang diiradiasi gamma. Sampai dosis 7,5 kGy, intensitas bercak sampai dosis 7,5 kGy tidak mengalami perubahan secara visual, warna kuning masih terlihat jelas. Pada dosis $10 \mathrm{kGy}$ intensitas warna ketiga bercak mengalami penurunan

Tabel 2. Uji aktivitas sitotoksik ekstrak terhadap sel leukemia L1210.

\begin{tabular}{cc}
\hline Ekstrak & $\begin{array}{c}\mathrm{IC}_{50} \\
(\mu \mathrm{g} / \mathrm{mL})\end{array}$ \\
\hline n-heksan & 8,29 \\
etil asetat & 4,17 \\
etanol & 7,52 \\
\hline
\end{tabular}

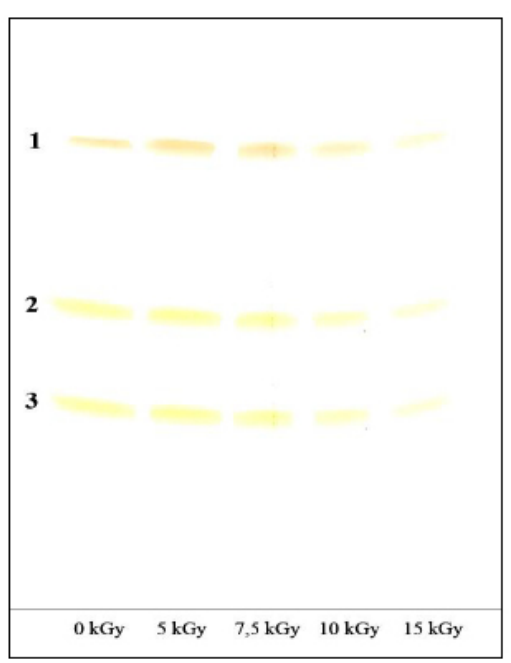

Gambar 1. Pola kromatogram dari kromatografi lapis tipis ekstrak etil asetat kontrol dan yang diiradiasi. Keterangan :

Fase diam : silika gel GF254

Fase gerak $\quad:$ kloroform : metanol (12:1)

Penampak bercak : serium sulfat $1 \%$ dalam asam sulfat $10 \%$ 
dan pada dosis $15 \mathrm{kGy}$ terlihat ketiga spot kuning makin memudar. Hal ini menunjukkan bahwa terjadi pengaruh iradiasi gamma pada intensitas warna spot pada profil KLT ekstrak etil asetat kontrol dengan yang diiradiasi $>10 \mathrm{kGy}$, hal ini diduga diakibatkan adanya kerusakan komponen akibat iradiasi gamma.

Efek iradiasi gamma seperti ini juga dijelaskan oleh Winarno ${ }^{(8)}$ daging buah mahkota dewa yang diiradiasi gamma pada sampel yang diiradiasi dengan dosis 5; 7,5 dan $15 \mathrm{kGy}$, bercak nomor 7-9 menurun densitasnya secara visual, sedangkan pada iradiasi dosis 20 kGy bercak 7-9 tidak terlihat lagi, bercak 6 dan 10 menurun densitasnya. Hal ini diduga karena efek langsung radiasi yang dapat menyebabkan materi terionisasi sehingga dapat mengalami perubahan baik secara fisika maupun secara kimia ${ }^{(9)}$.

Hasil fraksinasi diperoleh 6 fraksi yang dilanjutkan pengujian uji aktivitas sitotoksik sampel kontrol ( 0 kGy) fraksi-fraksi terhadap sel leukemia L1210 yang hasilnya dapat dilihat pada Tabel 3. Berdasarkan nilai $\mathrm{IC}_{50}$ diketahui bahwa semua fraksi (6 fraksi) berpotensi aktif sebagai anti kanker (nilai $\mathrm{IC}_{50}<20 \mu \mathrm{g}$ / $\mathrm{mL}$ ) dengan fraksi 1 yang paling aktif dengan nilai $\mathrm{IC} 50=3,66 \mu \mathrm{g} / \mathrm{mL}$.

Nilai $\mathrm{IC}_{50}$ fraksi 1 dari ekstrak etil asetat kulit buah manggis yang tidak dan yang diiradiasi gamma dosis 5; 7,5; 10 dan 15 kGy ditunjukkan pada Gambar 2. Hasil uji sitotoksik fraksi 1 terhadap sel leukemia L1210 menunjukkan dengan jelas bahwa dengan peningkatan dosis iradiasi, nilai $\mathrm{IC}_{50}$ mengalami

Tabel 3. Uji aktivitas sitotoksik fraksi dari ekstrak etil asetat kulit buah manggis terhadap sel leukemia L1210.

\begin{tabular}{cc}
\hline Fraksi & $\begin{array}{c}\mathbf{I C}_{\mathbf{5 0}} \\
(\boldsymbol{\mu g} / \mathbf{m L})\end{array}$ \\
\hline $\mathbf{1}$ & $\mathbf{3 , 6 6}$ \\
2 & 4,07 \\
3 & 4,26 \\
4 & 4,20 \\
5 & 4,68 \\
6 & 4,75 \\
\hline
\end{tabular}

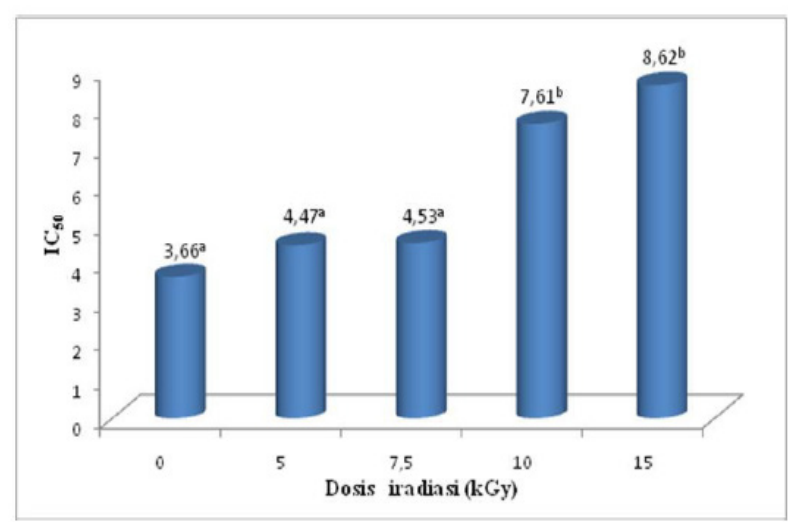

Gambar 2. Diagram pengaruh iradiasi gamma pada aktivitas sitotoksik $\left(\mathrm{IC}_{50}\right)$ fraksi 1 dari ekstrak etil asetat kulit buah manggis. penurunan. Sampai dengan dosis iradiasi $15 \mathrm{kGy}$, nilai $\mathrm{IC}_{50}$ yang diperoleh masih aktif sebagai anti-kanker $\left(\mathrm{IC}_{50} \leq 20 \mu \mathrm{g} / \mathrm{mL}\right)^{(7)}$.

Dari hasil analisis statistik tersebut diperoleh hasil bahwa antara kontrol (0 kGy) sampai dengan dosis iradiasi 7,5 kGy tidak terdapat perbedaan bermakna. Sedangkan untuk kontrol dengan dosis 10 dan 15 kGy terdapat perbedaan bermakna. Berdasarkan hasil tersebut iradiasi gamma $>10 \mathrm{kGy}$ diduga adanya efek langsung iradiasi berupa ionisasi pada materi tersebut. Semakin besar dosis iradiasi gamma yang diberikan, maka semakin besar daya ionisasinya sehingga akan menyebabkan terjadinya perubahan fisik-kimia ataupun kerusakan komponen yang ada di dalam kulit buah manggis. Bila perubahan terjadi pada senyawa metabolit sekunder yang berpotensi anti kanker, maka berdampak pada aktivitas komponen-komponen tersebut terhadap sel leukemia L1210.

Identifikasi pada spektrum UV-Vis fraksi 1 dari ekstrak etil asetat kulit buah manggis ditunjukkan pada Gambar 3. Terdapat 3 puncak utama yaitu pada panjang gelombang 203, 244, dan $317 \mathrm{~nm}$ di daerah ultraviolet (200-400 nm), hal ini berarti bahwa fraksi 1 mengandung komponen flavonoid. Pengaruh iradiasi gamma pada spektrum kromatogram menyebabkan penurunan jumlah serapan seiring dengan peningkatan dosis iradiasi. Pengaruh iradiasi gamma pada senyawa flavonoid dalam strawberi tidak mengubah konsentrasi dari kuersetin dan turunan asam ellagat, namun menurunkan konsentrasi $(+)$ - katekin, diikuti oleh kaempferol-3-glukosida dan (-) - epikatekin secara signifikan $^{(10)}$. Senyawa golongan flavonoid dalam batang $S$. jacobinensis tetap menunjukkan kemampuan sebagai penangkap senyawa-senyawa radikal setelah diiradiasi dengan dosis $0,8 \mathrm{kGy}^{(11)}$.

Berdasarkan hasil analisis ANOVA pada nilai serapan fraksi 1 pada panjang gelombang 203, 244 dan $317 \mathrm{~nm}$ menunjukkan bahwa sampai dosis 7,5 kGy

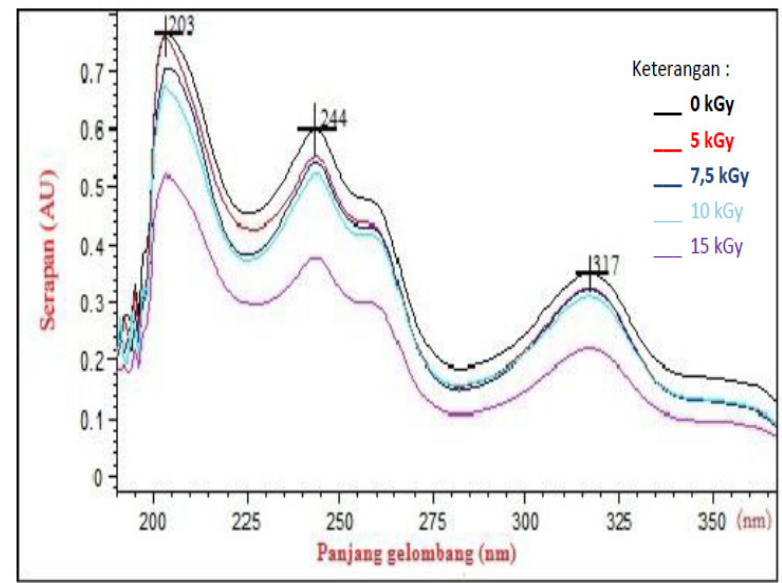

Gambar 3. Spektrum UV-VIS fraksi 1 dari ekstrak etil asetat kulit buah manggis. 
tidak ada perbedaan yang bermakna dibandingkan terhadap sampel yang tidak diiradiasi. Pada dosis $>10 \mathrm{kGy}$ serapan mengalami penurunan, hal ini menunjukkan adanya penurunan jumlah komponen golongan flavonoid. Angka serapan turun 8,33\% $(244 \mathrm{~nm})$.

Profil kromatografi lapis tipis fraksi 1 dari ekstrak etil asetat disajikan pada Gambar 4. Profil kromatografi lapis tipis pada Gambar A (254 nm) terdapat 4 bercak, dengan peningkatan dosis iradiasi terlihat adanya pemudaran bercak pada bercak 1, 2, dan 3 dosis iradiasi 7,5; 10; dan 15 kGy. Pada Gambar B terdapat 2 bercak, dengan .

Peningkatan dosis iradiasi terlihat adanya pemudaran bercak 1 dosis iradiasi 7,5; 10; dan 15 kGy. Pemudaran bercak yang terjadi kemungkinan

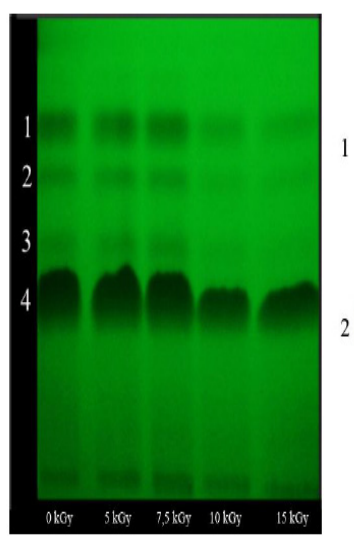

$0 \mathrm{kGy} \quad 5 \mathrm{kGy} \quad 7, \mathrm{kGy} \quad 10 \mathrm{kGy} \quad 15 \mathrm{kGy}$

Gambar 4. Kromatogram fraksi 1 dari ekstrak etil asetat kulit buah manggis yang tidak diiradiasi dan yang diiradiasi dosis 5; 7,5; 10 dan 15 kGy. Keterangan :

A $\quad$ : kromatogram diamati pada lampu uv $254 \mathrm{~nm}$

B : kromatogram setelah disemprot penampak bercak serium sulfat

Fase gerak : n-heksan : etil asetat (2:1)

Fase diam : silika gel GF254

Deteksi : sinar UV 254 dan $366 \mathrm{~nm}$

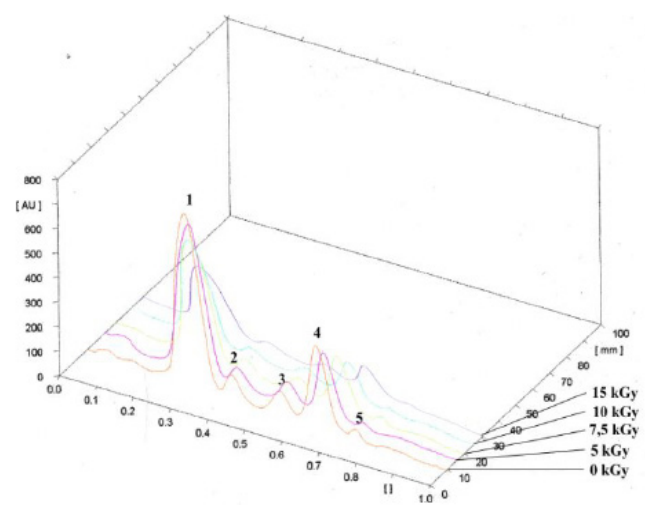

Gambar 5. Hasil analisis kromatografi lapis tipisdensitometri fraksi 1 dari ekstrak etil asetat kulit buah manggis pada variasi dosis iradiasi. diakibatkan kerusakan komponen akibat iradiasi gamma. Hasil profil kromatografi lapis tipis -densitometri, pada Gambar 5 menunjukkan terdapat 5 buah puncak dan puncak 1 adalah puncak utama karena memiliki luas area puncak yang paling besar. Secara umum luas puncak menurun seiring dengan peningkatan dosis iradiasi. Penurunan luas puncak kemungkinan disebabkan terjadinya kerusakan komponen akibat iradiasi gamma $>10 \mathrm{kGy}$. Hal ini juga didukung oleh adanya penurunan intensitas bercak pada KLT (Gambar 1 dan 4) dan penurunan serapan uv-vis larutan fraksi 1 (Gambar 3).

Hasil analisis KCKT dilakukan terhadap fraksi paling aktif (fraksi 1 dari ekstrak etil asetat) dari sampel yang diiradiasi pada dosis $5 ; 7,5 ; 10 ; 15 \mathrm{kGy}$ dan dari sampel yang tidak diiradiasi. Semua sampel uji menunjukkan profil kromatogram yang sama, hanya ada 1 puncak dengan waktu retensi 9,01 menit (pada panjang gelombang $317 \mathrm{~nm}$ ).

Pada kromatogram hanya terlihat 1 puncak, namun komponen tersebut belum dapat dikatakan senyawa tunggal, diduga komponen ini terdiri dari lebih dari satu senyawa yang memiliki sifat fisika kimia yang sama terhadap kondisi KCKT yang digunakan. Pada Gambar 6 ditampilkan profil kromatogram KCKT fraksi 1 dari sampel yang tidak diiradiasi (A) dan yang diiradiasi 7,5 kGy (B) sebagai wakil. Tinggi dan luas puncak menurun seiring meningkatnya dosis iradiasi. Hal ini diduga adanya degradasi senyawa-senyawa yang memiliki serapan pada panjang gelombang 317 $\mathrm{nm}$, hal ini didukung pula oleh profil kromatogram analisis KLT-densitometri dan spektrofotometri UVVis.

Berdasarkan luas puncak utama masing - masing sampel yang tidak dan yang diiradiasi dibuat analisis statistik menggunakan anova satu arah (SPSS 20) pada taraf kepercayaan $95 \%(\alpha=0,05)$, hasilnya
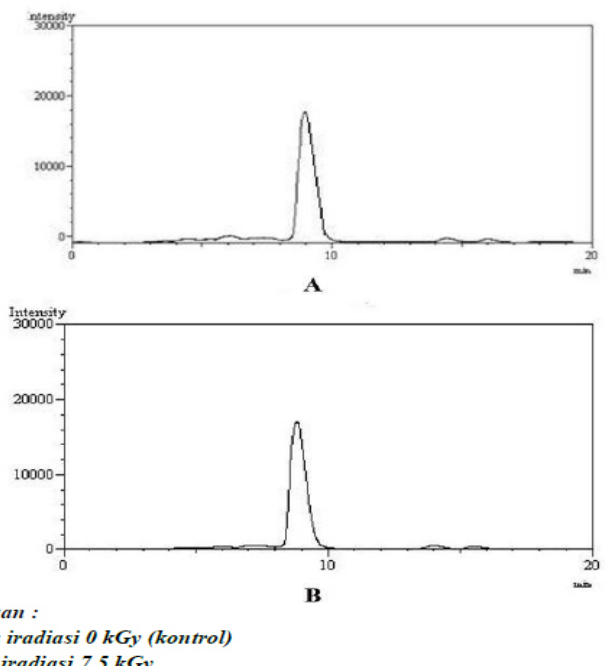

$A$ : Dosis iradiasi $0 \mathrm{kGy}$ (kontrol)

Gambar 6. Kromatogram KCKT fraksi 1 kontrol (A) dan yang diiradiasi 7,5 kGy (B). 
menunjukkan bahwa ada perbedaan luas bermakna antara kontrol dengan yang diiradiasi pada dosis $\geq 10 \mathrm{kGy}$. Dosis iradiasi gamma sampai dengan 7,5 kGy tidak menyebabkan perubahan luas area puncak komponen fraksi 1.

Penurunan aktivitas sitotoksik fraksi 1 dari ekstrak etil asetat sampel yang diiradiasi $>10 \mathrm{kGy}$ didukung oleh hasil profil KLT dan KLT-densitometri adanya pemudaran warna bercak dan penurunan serapan, hasil spektrum uv-vis serapan larutan dan luas area puncak pada kromatogram KCKT yang diperoleh mengalami penurunan. Namun demikian nilai $\mathrm{IC}_{50}$ fraksi aktif terhadap pertumbuhan sel leukemia L1210 masih dalam kategori aktif berpotensi sebagai antikanker $(<20 \mu \mathrm{g} / \mathrm{mL})$. Pada penelitian yang dilakukan oleh Yun Sung, sampel lektin (dari mistletoe segar yang tumbuh di pohon oak, Korea) dilarutkan dalam PBS ( $1 \mathrm{mg} / \mathrm{mL}$ (w/v) diiradiasi pada dosis 5, 10, 15, dan $20 \mathrm{kGy}{ }^{(12)}$.

Hasilnya menunjukkan bahwa dosis iradiasi gamma sebesar $5 \mathrm{kGy}$ berguna untuk mengurangi toksisitas lektin tanpa mengubah bioaktivitasnya sebagai anti kanker. Karena itu dosis maksimum yang digunakan untuk setiap jenis simplisia obat herbal berbeda-beda, karena itu perlu diuji besarnya dosis iradiasi gamma yang diperlukan agar bioaktivitasnya tidak berubah. Dosis iradiasi gamma untuk pengawetan serbuk kulit buah manggis dianjurkan tidak melebihi 7,5 kGy.

\section{SIMPULAN}

Sitotoksisitas fraksi 1 dari kulit buah manggis yang diiradiasi 7,5 $\mathrm{kGy}\left(\mathrm{IC}_{50}=4,53 \mu \mathrm{g} / \mathrm{mL}\right)$ tidak berbeda nyata dengan kontrol $\left(\mathrm{IC}_{50}=3,66 \mu \mathrm{g} / \mathrm{mL}\right)$. Profil spektrum, KLT, KLT-densitometri, dan KCKT fraksi paling aktif(fraksi 1) dari ekstrak etil asetat kulit buah manggis tidak mengalami perubahan oleh pengaruh iradiasi gamma, tetapi mempengaruhi terhadap luas puncak masing-masing kromatogram. Dosis iradiasi gamma maksimum untuk serbuk kulit buah manggis dengan tetap mempertahankan aktivitas sitotoksiknya terhadap sel leukemia L1210 adalah 7,5 kGy.

\section{UCAPAN TERIMAKASIH}

Terima kasih disampaikan kepada saudara Susanto dan para staf di Balai Instrumentasi Elektronika dan Iradiasi-PAIR yang telah membantu sehingga penelitian ini dapat terlaksana dengan baik.

\section{DAFTAR PUSTAKA}

1. Data statistik export buah manggis dari Indonesia tahun 2010. diambil dari: http://pphp.deptan.go.id/ disp_informasi/1/5/54/1291/potensi_peluang_ekspor_ manggis_indonesia.html. diakses $25 \mathrm{Mei}, 2012$.

2. Materi Pelatihan Profesional Tanaman Obat (Kelas Profesional). Buku 2 tanaman obat. Jakarta: Karyasari; 1999. 13-4.

3. Gutierrez-Orozco F and Failla ML. Review biological activities and bioavailability of mangosteen xanthones: a critical review of the current evidence. Nutrients. 2013. 5:3163-83.

4. Lourith N and Kanlayavattanakul M. Biological activity and stability of manggosteen as a potential natural color. Biosci Biotechnol Biochem. 2011. 75 (11):2257-59.

5. Januwati M. Peran teknik nuklir dalam argoindustri tanaman obat. Risalah Seminar Ilmiah Aplikasi Isotop Dan Radiasi. Jakarta: BATAN; 2006. 8-27.

6. Winarno $\mathrm{H}$ and Katrin E. Benzophenone glucoside isolated from the ethyl acetate extract of the bark of Mahkota Dewa (Phaleria macrocarpa (Scheff.) Boerl.) and its inhibitory activity on leukemia L1210 cell line. Indo J Chem. 2009. 8(1):142-5.

7. Hostettmann K. Assays related to cancer drug discovery. Dalam Buku: Assays for Bioactivity. Volume 6. Institute of Pharmacognosy and Phytochemistry. University of Lausanne Switzerland. 1991. 84.

8. Winarno EK, Mazda, Rahmawati H, dan Winarno H. Pengaruh iradiasi gamma pada aktivitas sitotoksik daging buah mahkota dewa (Phaleria macrocarpa (Scheff) Boerl.). Jurnal Sains dan Teknologi Nuklir Indonesia Indonesian. 2010. XI(2): 67-76.

9. Charoen $\mathrm{S}$ and Aemsiri J. Effects of gamma irradiation on microbiological and chemical quality of herbal teas. Proc Int'l Symp on New Frontier of Irradiated Food and Non-Food Products. KMUTT, Bangkok; 2005.

10. Breitfellner F, Solar S, and Sontag G, Effect of gamma irradiation on flavonoids in strawberries. European Food Research and Technology. 2002. 215(1): 28-31.

11. Fernando de Melo Vaz A, Pessoa de Souza M, et al. FNS Stability of the antioxidant activity of flavonoids after gamma irradiation. Food and Nutrition Sciences. 2011. 2: 490-3.

12. Sung NY, Byuna EB, et al. Effect of gamma irradiation on mistletoe (Viscum album) lectin-mediated toxicity and immunomodulatory activity. FEBS Open Bio. 2013. 3:106-11. 